\title{
Telecommunication Regulation in Bangladesh: An overview
}

\author{
Anju Man Ara Begum* \\ Mohammad Hasan Murad ${ }^{* *}$ \\ Kazi Arshadul Hoque
}

\begin{abstract}
The demand for telecommunications services is rapidly escalating. There has been a significant shift from domestic intrasufficiency to international interdependence in both the demand and supply sides of markets generally. As consumers become more sophisticated in evaluating the world market, businesses have to maintain their comparative advantage in services by globalizing research, manufacturing products with multinational counterparts. All of these factors- the high demand for telecommunications services, the interconnectedness of telecommunications sector inputs and uses, and international dependence-created the need to integrate the piecemeal and segmented Telecommunications trade policies, laws and regulations. This article begins by looking at the question 'what is telecommunications?' and then by identifying reasons why the industry is so highly regulated. The discussion is then led into the general way in which telecommunications is regulated and finally specifically at how it is regulated in Bangladesh. This article is intended to provide a big-picture overview of how telecommunications is regulated in Bangladesh. Recommendations are also suggested to improve the regulatory framework of telecommunication in Bangladesh.
\end{abstract}

\section{Introduction}

During the beginning of $20^{\text {th }}$ century we have seen revolusioary changes in the telecommunication sector due to technology revolution

\footnotetext{
* Lecturer, Department of Law, International Islamic University Chittagong.

** Assistant Professor, Department of Law, International Islamic University Chittagong.

*** Assistant Professor, Department of Law, International Islamic University Chittagong.
} 
and explosive demand of telecommunication services. Some countries have responded unilaterally to the changes in telecommunications by privatizing and deregulating their domestic markets. Through privatization, the government transforms the telecommunications sector from a state owned and operated enterprise into a private enterprise, although the private enterprise can maintain a monopolistic position. Through liberalization, the government allows many enterprises to compete effectively for consumer demand.

However, the most profound impact on the global telecommunications markets has come from the concluded multilateral negotiations on basic telecommunications services in the World Trade Organization (WTO) under the auspices of the General Agreement on Trade in Services (GATS) ${ }^{1}$.

The results of these negotiations were the driving force behind a wave of countries liberalizing their trade laws to ease the harshness and complexity of providing telecommunications services over national borders. The liberalization of Bangladesh's telecommunications sector began with small steps in 1989 with the issuance of a license to a private operator for the provision of inter alia cellular mobile services to compete with the previous monopoly provider of telecommunications services the Bangladesh Telegraph and Telephone Board (BTTB). Significant changes in the number of fixed and mobile services deployed in Bangladesh occurred in the late 1990s and the numbers of services in operation have subsequently grown exponentially in the past years after the enactment of the Bangladesh Telecommunication Act, 2001.

The incentives both from government and public sectors have helped to grow this sector. It is now one of the biggest sectors of Bangladesh. As a populous country, its huge market has attracted many foreign investors to invest in this sector.

\subsection{Definition of Telecommunication}

Etymologically, 'tele' means distance and 'communication' means exchange of ideas. So, Telecommunication means exchange of ideas and information from a distance.

'Telecommunications' is defined in Newton's Telecom Dictionary as: 
The art and science of 'communicating' over a distance by telephone, telegraph and radio. The transmission, reception and the switching of signals, such as electrical or optical, by wire, fibre, or electromagnetic (ie through-the-air) means. ${ }^{2}$

The International Telecommunication Union defines telecommunication as follows:

Any transmission, emission or reception of signs, signals, writings, images and sounds or intelligence of any nature by wire, radio, optical or other electromagnetic systems. ${ }^{3}$

The above definitions embody two ideas. The first is the action of communicating, in other words, conveying and receiving information. The second is the means and methods of communicating, in other words, communications infrastructure.

The Constitution of The People's Republic of Bangladesh, 1971 implicitly guarantees freedom of communication. Article 39 outlines:

1. Freedom thought and on consciences guaranteed.

2. Subject to any reasonable restrictions imposed by law in the interests of the security of the State, friendly relations with foreign states, public order, decency or morality, or in relation to contempt of court, defamation or incitement to an offence-

a) the right of every citizen to freedom of speech and expression; and

b) freedom of the press, are guaranteed.

An analysis of the above article guaranteeing freedom of expression reveals that the article also covers the right to communicate as freedom of expression can hardly be realized if communication is not facilitated. The right to freedom of expression has to be interpreted to mean not only the right to speak and the right to hear speech but also the right to have access to the means by which to communicate such speech.

The principal legislation in the field of telecommunication is the Bangladesh Telecommunication Act, 2001 which defines telecommunication in the following way: 
'telecommunication' means transmission and reception of any speech, sound, sign, signal, writing, visual image or any other intellectual expression by way of using electricity or electro-magnetic or electrochemical or electro-mechanical energy through cable, pipe, radio, optical fibre or other electromagnetic or electro-chemical or electromechanical or satellite communication system. ${ }^{4}$

\subsection{Need for regulating telecommunication}

In each and every country and in international sphere also, there are special laws and policies in order to regulate telecommunication. Over the years, we have seen a tremendous growth in the regulatory regime in telecommunication sector both in number and complexity. The reasons for heavy regulations in this industry is outlined as under-

Firstly, before liberalization, telecommunication industry was monopolized by the Government as well as a few private sector enterprises. Liberalization in telecommunication sector has brought a paradigm shift from monopoly to competition which attracted regulatory intervention in a comprehensive way. The regulations of interconnection and pricing are the critical steps by regulators in the transition from a monopoly to a competitive market.

Secondly, the telecommunications sector in Bangladesh has been characterized by a very low level of penetration, limited capability to meet the growing demand, low level of investment and old outdated systems and technologies necessitating reactive remedial measures. In order to develop a national sound telecommunication infrastructure to support the economy and welfare of the country by providing telecommunication facilities on demand, assuring satisfactory quality of service and ensuring value to the customers, a sound National Telecommunication Policy( and regulations) are essential. ${ }^{5}$

Thirdly, the existence of a functioning regulatory regime means the investors will feel safe to invest in a level playing field free from anticompetitive practices.

Fourthly, the radio frequency spectrum is considered to be a valuable limited national resource. It has been maintained by different national governments that control must be exercised on the allocation and usage of the radio frequency in order to check anarchy and disorder. 
This stance of national governments will continue to be dominant until the new technologies emerge to make radio frequency more abundant.

\subsection{How Telecommunications is regulated}

In regulating telecommunication both national and international laws are applied since telecommunication is not restricted within national borders. In constitutional states domestic regulations relating to telecommunication derive their validity from the Constitution. There is a number of legislation specific to telecommunication. They are supplemented by the general legislations such as contract law and competition policy law.

A specialized entity is also created in order to regulate and oversee issuing licenses, resolving disputes and making more detailed rules for the industry. Often, the regulator is independent of both the government and the various players in the industry. Sometimes the various regulatory functions are shared by different government entities. The courts also play a vital role in the process of settling disputes and framing rules through rulings and findings.

Bangladesh follows the general model of telecommunication regulatory framework. The following diagram shows the general regulatory regime of telecommunication in Bangladesh.

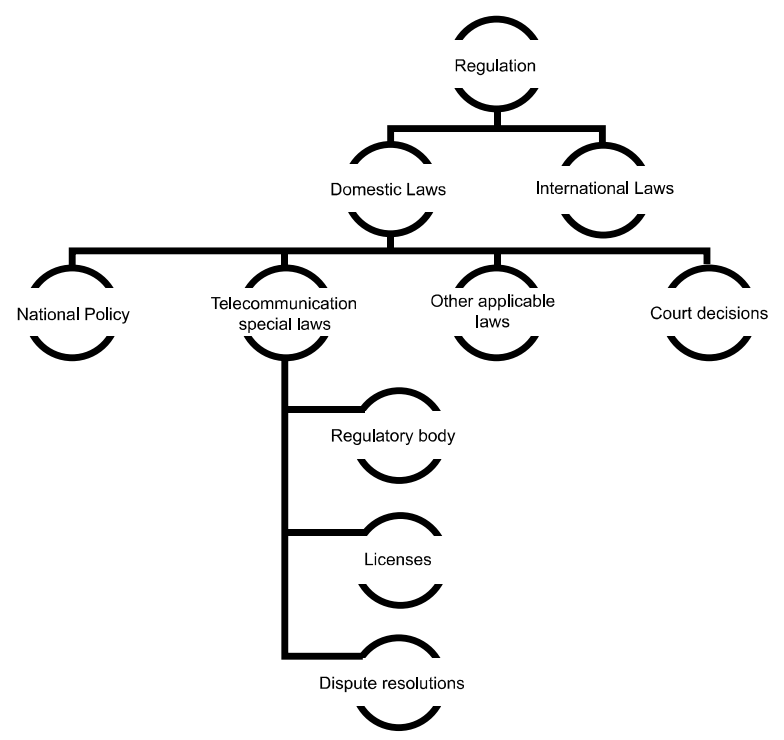

Figure 1: The telecommunication regulatory framework 


\subsection{How telecommunication is regulated in Bangladesh}

\subsubsection{Supremacy of Constitution}

Like any other Constitutional state, the Constitution is the supreme law of the land of Bangladesh. All legislation must be consistent with it and all acts of the government must be consistent with it. Just as legislation must be consistent with the Constitution, subordinate legislation, such as regulations, must be consistent with both the legislation in terms of which it is made, and the Constitution. For example, sections 98 and 99 of the Bangladesh Telecommunications Act empower the Government as well as the regulator, Bangladesh Telecommunication Regulatory Commission, to make regulations, which must be consistent with the Telecommunications Act and with the Constitution. ${ }^{6}$

\subsubsection{National policy}

National policy is a broad course of action adopted by a Government in pursuit of some specific objectives. National policy should be articulated in such way that the goals and methods that have been set out are practical and achievable. National policy is the responsibility of the national executive i.e. the relevant ministries and departments of the Government. In Bangladesh there are four major policies addressing the Telecommunication sector.

a. National Telecommunication Policy, 1998.

b. National Information Communication Technology (ICT) Policy, 2002.

c. International Long Distance Telecommunications Services (ILDTS) Policy, 2010.

d. National Broadband Policy, 2009.

\section{National Telecommunication Policy, 1998}

This policy was formulated by Ministry of Post and Telecommunications. This National Telecommunications Policy is a summary statement of the philosophy, objectives, strategies and the methodology to ensure equitable and judicious execution of the business of telecommunications in the country. According to the policy, the Strategic Vision of the Government is to facilitate Universal Telephone Service throughout the country and where there is a demand, all those value added services such as cellular mobile 
telephone paging, data services, access to Internet (including electronic mail), voice mail and video conferencing - all at an affordable cost without compromising performance.

This policy has to be updated to keep pace with the ever-developing world of telecommunication. Any future amendment to the policy must address the convergence issues of Information of communications technology.

\section{National Information Communication Technology (ICT) Policy, 2002}

Ministry of Science and Information \& Communication Technology of the Government of Bangladesh framed the ICT policy with the aim to building an ICT-driven nation comprising of knowledge-based society. In view of this, a country-wide ICT-infrastructure will be developed to ensure access to information by every citizen to facilitate empowerment of people and enhance democratic values and norms for sustainable economic development by using the infrastructure for human resources development, governance, e-commerce, banking, public utility services and all sorts of on-line ICT-enabled services. ${ }^{7}$

The objectives of the policy outline some clauses relating to telecommunication:

a. Development of telecommunication infrastructure should be considered as Infrastructure Development Industries like Development of Road, Electricity, Power, Computer/ICT Industry etc.

b. Facilitate development of telecommunication infrastructure at the least possible cost with little or no customs duty during construction of the infrastructure up to June, 2006.

c. As telecommunication infrastructure [Telephone Exchange, Towers, Radio/Telephone Transmission Lines etc.] are similar to electric power infrastructure [Generator, Pylons, Power Grid and Gas Transmission Lines], so Customs Duty \& Tax etc. should be amended accordingly in the same line .

d. Cellular telephone handsets are being increasingly used as terminals for emailing and other ICT uses. Customs duty \& tax etc. of cellular mobile telephone handsets should be brought down to a reasonable level. 
e. Telecommunication facility will be made available to all segments of the society and all of the present and emerging services will be provided at an affordable cost.

f. To improve the quality of present telecommunication services and to help provide value added services analog telephoneswitches and transmission link of the existing telephone network will be replaced by digital switches and digital transmission link as early as possible.

\section{International Long Distance Telecommunications Services (ILDTS) Policy, 2010}

This policy has been formulated by Ministry of Post and Telecommunications in order to address the pressing issues that emerged during regulation of technologies of long distance calls especially through Voice Over Internet Protocol Services (VoIP). VoIP has been very popular among the users as it provides inexpensive voice communication over the internet all over the world. VoIP has been the catch phrase in Bangladesh for quite some time. The issues of VoIP could not be addressed in the previous telecom policy of 1998 and in the Bangladesh Telecommunications Act, 2001 as its success was not conceived in that time. Amidst confusion and delays in regulating VoIP services, many secret operations of VoIP services mushroomed depriving a huge amount of revenue to the Government. The new policy is formulated in order to regulate the call forwarding service of long distance international calls through approved technologies including VoIP.

\section{National Broadband Policy, 2009}

Right to Internet Access or Right to Broadband is considered to be an ancillary right to exercise and enjoy Right to Freedom of Expression and Right to Information. ${ }^{8}$ Ministry of Post and Telecommunications unveiled National Broadband Policy in 2009. The broad objective of the policy is to provide broadband internet access across the country and set an ambitious target of broadband penetration of $30 \%$ throughout the country by the year 2015 . The policy not only puts stress on internet infrastructure growth but also gives emphasis on local internet content development. 


\subsubsection{National Legislation}

\section{The Telegraph Act, 1885}

The history of telecommunication legislation in Bangladesh dates back to 1885 when the first specific telecommunication law the Telegraph Act, 1885 was passed. Although the Act has not been repealed by the subsequent legislation, it has almost lost its practical application since telegraph services are obsolete now. Despite that, a few provisions of the Act could still be applied in supplement with the latest laws. For example, section 5 of the Act dealing with interception of message and communication is still operative.

\section{The Wireless Telegraphy Act, 1933}

The preamble of the Act states that this is an Act to regulate the possession of wireless telegraphy apparatus. This is a short Act containing only 11 sections. Section 3 prohibits possession of wireless telegraphy apparatus without obtaining a license the procedure of which is outlined in section 5 . Whoever possesses wireless telegraphy without license shall be punished with a fine of one hundred taka and for subsequent offences a fine of two hundred fifty taka will be imposed on the offender.

\section{The Bangladesh Telecommunication Act, 2001}

Enactment of the Bangladesh Telecommunication Act, 2001 was a significant step from Bangladesh government to liberalize the telecommunication sector of Bangladesh. The major duties of regulating the sector are transferred to newly created and independent commission known as Bangladesh Telecommunications Regulatory Commission (BTRC). The preamble of the Act goes:

An Act to provide for the establishment of an independent Commission for the purpose of development and efficient regulation of telecommunication system and telecommunication services in Bangladesh and matters ancillary thereto ; whereas it is expedient to provide for the establishment of an independent Commission for the purpose of development and efficient regulation of telecommunication system and telecommunication services in Bangladesh and for the transfer of the 
powers and functions of the Ministry of Post and telecommunication to the Commission and matters ancillary thereto.

The Act sets out the fundamentals rules of telecommunication in Bangladesh. For example, section 35 states that no person will establish telecommunication and internet services without a license under the Act. Similarly, section 55 prohibits use of radio frequency without the license from the Authority. Sections 47 of the Telecommunication Act require licensees under the Act to interconnect with and provide telecommunication facilities to any other licensee if certain conditions exist.

Under section 6 an independent commission is established as a principal regulatory body for the telecommunication sector named as Bangladesh Telecommunication Regulatory Commission. The many functions of the commissions include regulating the establishment, operation and maintenance of telecommunication services in Bangladesh. ${ }^{9}$ BTRC is given specific powers under the Act to make regulations in the matters as outlined in the following table:

\begin{tabular}{|c|l|}
\hline Section & \multicolumn{1}{|c|}{ Subject matter of regulation } \\
\hline Section 36 (5) & $\begin{array}{l}\text { The manner in which licenses for } \\
\text { telecommunication services have to be made to } \\
\text { the commission. }\end{array}$ \\
\hline Section 55 (3) & $\begin{array}{l}\text { The manner of issuance of license for radio } \\
\text { frequency, allocation of frequency, and their } \\
\text { renewal, suspension and cancellation, the } \\
\text { qualifications and disqualifications of a } \\
\text { licensee, the license-fees and other related } \\
\text { matters. }\end{array}$ \\
\hline Section 31 (2) h & $\begin{array}{l}\text { Issuance of guidelines on matters of } \\
\text { interconnection among operators, to determine, } \\
\text { in appropriate cases, the conditions applicable } \\
\text { thereto. }\end{array}$ \\
\hline Section 31 (2) g & $\begin{array}{l}\text { Issuance of guidelines on matters not } \\
\text { sufficiently provided in the Act or regulations } \\
\text { and, in appropriate cases, to give decisions as } \\
\text { the Commission may deem proper and to issue } \\
\text { orders accordingly. }\end{array}$ \\
\hline Section 31 (2) r & $\begin{array}{l}\text { issuance and publishing instructions to be } \\
\text { followed in relation to activities of the }\end{array}$ \\
\hline
\end{tabular}




\begin{tabular}{|c|l|}
\hline & $\begin{array}{l}\text { Commission under the Act, instructions to be } \\
\text { followed by licensees and service providers and } \\
\text { also instructions on matters relating to terminal } \\
\text { apparatus, telecommunication apparatus, } \\
\text { interference causing apparatus, radio frequency } \\
\text { and radio apparatus. }\end{array}$ \\
\hline Section 51 (2) a & $\begin{array}{l}\text { The Commission may, for different class of } \\
\text { apparatus, determine different standards, criteria } \\
\text { and method for verifying their compliance. }\end{array}$ \\
\hline \multirow{3}{*}{ Section 54 } & $\begin{array}{l}\text { The Commission may, by making regulations or } \\
\text { by publishing notice at least in two widely } \\
\text { circulated national dailies, determine the } \\
\text { standards of various telecommunication } \\
\text { services, and in providing those services, the } \\
\text { operators shall be bound to follow those } \\
\text { standards. }\end{array}$ \\
\hline Section57 (4) a,b & $\begin{array}{l}\text { The Commission is empowered to make } \\
\text { regulations relating to Technical Acceptance } \\
\text { Certificate. }\end{array}$ \\
\hline Section 99 & $\begin{array}{l}\text { For carrying out the purposes of this Act, the } \\
\text { Commission may, by notification in the Gazette, } \\
\text { make regulations consistent with this Act and } \\
\text { the rules made by the Government. }\end{array}$ \\
\hline
\end{tabular}

\section{The Information and Communication Technology Act, 2006}

The primary object of the Information and Communication Technology Act, 2006(the ICT Act) is to provide legal validly and security to information and communication technology and to make rules in relation to that. ${ }^{10}$ This Act, however, does not regulate telecommunication sector in the manner of the Telecommunication Act. The significance of the ICT Act in relation to telecommunication lies in the fact that the Act removes and explains some of the legal uncertainties in relation to information and communication technology.

The ICT Act deals with some specific subject matter:

a. Authentication by Electronic Signature. ${ }^{11}$

b. Legal recognition of Electronic Records. ${ }^{12}$

c. Communication of Electronic Records. ${ }^{13}$ 
d. Electronic Gadget. ${ }^{14}$

e. Certification Authority. ${ }^{15}$

f. Licenses ${ }^{16}$

g. Cybercrimes and punishment. ${ }^{17}$

h. Cyber tribunal. ${ }^{18}$

\section{The Competition Act, 2012}

The Competition Act is the newest addition to the list of legislations that may be used to regulate the telecommunication industry in Bangladesh. The Act is aimed at encouraging and ensuring more healthy competition atmosphere in the market in general. The Telecommunication Act already contains detailed provisions in respect of maintaining competition in Telecommunication industry. The Competition Act is not an industry specific Act. It deals with improving general completion scenario in Bangladesh. It applies inter alia to the telecommunications industry. Section 3 of the Competition Act indicates that it applies to all businesses providing trading of goods and services or engaged in manufacturing, supplying or storing of goods. Since telecommunication is involved in trading of hardwires , software and providing services, the sector will come under the ambit of the Act. Section 42 of the Competition Act states that,

"The provisions of this Act shall be in addition to, and not in derogation of, the provisions of any other law for the time being in force. Provided that in order to ensure the fulfillment of the objectives of this Act, the provisions of this Act shall get preference."

Clearly, this section establishes concurrent jurisdiction of the Competition Act along with the Telecommunication Act in matters relating to competition.

The Competition Act sets out some basic rules concerning competition. Chapter 3 prohibits certain anti-competitive practices. Section 15(1) prohibits agreements or practices between parties in horizontal relationship if such agreements or practices cause or likely to cause an appreciable adverse effect on competition within Bangladesh. Price fixing, dividing markets, bid rigging, collusive tendering are per se considered anti-competitive practices. ${ }^{19}$ The Act also prohibits agreements between parties in a vertical relationship if 
such agreements are anti-competitive. ${ }^{20}$ Section 16 of the Competition Act prohibits abuses of dominant positions. Such abuses include predatory pricing, restricting production and scientific development, indulging in practice or practices resulting in denial of market access, forcing other parties to accept unrelated contractual obligations and using dominant position to protect other markets.

The Competition Act sets out the rules with regard to 'combination'. ${ }^{21}$ Combination means acquisition, acquisition of control, merger and amalgamation. ${ }^{22}$ Any combination must be approved by the Competition Commission. Combination generally will not be approved if they are found anti-competitive.

The Competition Act also establishes the Competition Commission. ${ }^{23}$ The functions of the Competition Commission include the investigation of anti-competitive vertical and horizontal agreements and practices, abuses of dominant positions, combination of business enterprises and prosecution of crimes under the Act. ${ }^{24}$

\subsubsection{International Law}

The telecommunication sector of Bangladesh is obligated to be regulated by international law in addition to the domestic laws and regulations. Bangladesh is a signatory to the Final Act Embodying the Results of the Uruguay Round of Multilateral Trade Negotiations which includes the Agreement Establishing the World Trade Organization and General Agreement on Trade in Services (GATS). Generally, Gats provides that any signatory country cannot treat service providers from other countries any less favourably than it treats service providers from its own country. ${ }^{25}$ This is known as the 'most favoured nation treatment' principle. Gats also requires all laws affecting trade in services to be published. ${ }^{26}$ However as a least developed country(LDC), Bangladesh has been exempted from making all sorts of reduction commitments (such as reduction of tariffs, domestic supports, etc). Bangladesh has also no obligation to open up any mode or sectors relating to trade in services in Doha round. $^{27}$

Bangladesh is an active member of International Telecommunication Union (ITU) which is a United Nations' specialized agency for information and communication technologies. Ministry of Post and Telecommunications of Bangladesh is responsible to co-ordinate participation of Bangladesh in the activities of the International 
Telecommunication Union and other international organizations regarding policies, standards and procedure to be followed in telecommunication and training on such matters. ${ }^{28}$ Bangladesh Telecommunication Regulatory Commission is also entrusted with the duty of assisting the concerned Ministries in matters of the International Telecommunication Union and other international and regional organizations relating to the standards and procedure to be followed in telecommunication; to collect the notices of the International Telecommunication Union and information on all relevant matters and to inform the relevant organizations of Bangladesh of those matters. ${ }^{29}$

\section{Conclusion}

Over the last decade, Bangladesh has made significant progress in regulating and encouraging telecommunication sector. The cellular technology is transforming many lives in Bangladesh. The affordability and availability of telecom services have increased many folds resulting in greater telecom density as envisaged in various policy documents. The recent boom in cellular phone services would not have been possible if market was not opened to competition in 2001. In the light of discussion in the article we can gather some points that the regulator should address in near future. They are:

a. Some out dated and out of context laws such the Telegraphy Act should be repealed.

b. The Telecommunication and ICT policy should be updated every year to keep pace with the rapidly developing technology.

c. A convergence policy has to be formulated so that convergence of technologies in broadcasting and telecommunications can be appropriately addressed.

d. Introduction of mobile number portability. ${ }^{30}$

e. Technological and policy barriers should be lifted in popularizing modern fast paced technologies such as $4 \mathrm{~g}$ networks.

f. The Telecommunication Act should be amended to provide statutory guideline for facilities leasing.

g. A detailed policy has to be made to address the lawful interception of communication. 
h.Policy has to be taken to introduce universal service and universal access to telecommunication to every household in Bangladesh.

\section{References}

1 General Agreement on Trade in Services, Annex on Telecommunications, Apr. 15, 1994, Marrakesh Agreement Establishing the World Trade Organization. WTO, Annex 1B, THE RESULTS OF THE URUGUAY ROUND OF MULTILATERAL TRADE NEGOTIATIONS: THE LEGAL TEXTS 359 (GATT Secretariat 1994), 33 I.L.M. 44, 73 (1994.

2 H Newton Newton's Telecom Dictionary 18 ed (2002) 733.

3 The Constitution of the International Telecommunication Union (Geneva, 1992) (CS 1012) (and RR No. 1.3).

4 Clause 11 of Section 2, the Bangladesh Telecommunication Act, 2001.

5 National Telecommunication Policy, 1998

6 Article 7 of The Bangladesh Constitution states," ... This constitution is, as the solemn expression of the will of the people, the supreme law of the republic, and if any other law is inconsistent with this constitution that other law, shall to the extent of the inconsistency be void".

72.1 Vision clause of ICT Policy, 2002.

8 N. Lucchi, "Access to Network Services and Protection of Constitutional Rights: Recognizing the Essential Role of Internet Access for the Freedom of Expression", Cardozo Journal of International and Comparative Law (JICL), Vol. 19, No. 3, 2011. Available at http://www.cjicl.com/uploads/2/9/5/9/2959791/cjicl_19.3_lucchi_ar

9 Section 30(1).a of the Bangladesh Telecommunication Act, 2001

10 Preamble to the Information and Communication Technology Act, 2006 (hereinafter The ICT Act)

11 Chapter II of the ICT Act

12 Id.

13 Chapter III of the ICT Act

14 Section 10 of the ICT Act

15 Chapter VI of the ICT Act

16 Id. 
17 Chapter VIII part I of the ICT Act

18 Chapter VIII Part II of the ICT Act

19 Section 15 (2) of the Competition Act, 2012

20 Section 15 (3) of the Competition Act, 2012

21 Section 21 of the Competition Act, 2012

22 Section 3 e of the Competition Act, 2012

23 Section 5 of the Competition Act, 2012

24 Section 8 of the Competition Act, 2012

25 Article II of Part II of Gats.

26 Article III of Part II of Gats.

27 http://www.mincom.gov.bd/wto.php accessed on September 10, 2012

28 Mission Statement, Ministry of Post and Telecommunications, http://www.mopt.gov.bd/all\%20backup/missionvision.htm accessed on September 12,2012

29 Section 30 (2) F of the Bangladesh Telecommunication Act ,2001

30 Mobile number portability (MNP) enables mobile telephone users to retain their mobile telephone numbers when changing from one mobile network operator to another. 